\title{
Investigasi Arus Sejajar Pantai (Longshore Current) di Daerah Abrasi Bengkulu Utara
}

\author{
Ashar Muda Lubis ${ }^{1 *}$, Nia Veronica ${ }^{1}$, Rio Saputra $^{1}$, Juhendi Sinaga', \\ M. Hasanudin², Edi Kusmanto2 \\ IJurusan Fisika, Fakultas Matematika dan Ilmu Pengetahuan Alam, Universitas Bengkulu \\ JI. WR. Supratman, Kadang Limun, Muara Bangkahulu, Bengkulu, 3837 I Indonesia \\ 2Pusat Penelitian Oseanografi, Lembaga Ilmu Pengetahuan Indonesia \\ Jl. Pasir Putih I, Ancol Timur, Jakarta 14430, Indonesia \\ Email: asharml@unib.ac.id
}

\section{Abstract \\ Longshore Current Investigation in Abrasion Prone Area, North of Bengkulu}

The coastal area of Serangai Village is directly facing the open sea; as a result it is vulnerable to coastal abrasion. Longshore currents can accelerate the process of coastal abrasion. The study was aimed to determine the speed and direction of current as well as the existence of the longshore current at the Serangai. Field observation was conducted on 5-7 November 2018. The results showed that the frequency distribution of current at speed of $0-10 \mathrm{~cm} / \mathrm{s}$ reached $69 \%$, and at speed of $10-20 \mathrm{~cm} / \mathrm{s}$ reached $25 \%$. The highest speed of $20-30 \mathrm{~cm} / \mathrm{s}$ has a frequency of $6 \%$. Moreover, the direction of the majority of ocean currents is to the southeast (1200-150\%), showing that the current is more likely to be parallel to the shoreline called longshore current that can accelerate shoreline Serangai Village, Bengkulu. However, further research is needed to see variability of current associated with the season (monsoon).

Keywords: Abrasion; Serangai; Aandera Seaguard RCM; Longshore Current

\begin{abstract}
Abstrak
Wilayah pesisir Desa Serangai berhadapan langsung dengan laut lepas; sehingga rentan terhadap abrasi pantai. Arus sejajar pantai dapat mempercepat proses abrasi pantai. Penelitian bertujuan untuk mengetahui kecepatan dan arah arus serta keberadaan arus sejajar pantai di Serangai. Pengamatan lapangan dilakukan pada tanggal 5-7 November 2018. Hasil penelitian menunjukkan bahwa distribusi frekuensi arus pada kecepatan $0-10 \mathrm{~cm} / \mathrm{s}$ mencapai $69 \%$, dan pada kecepatan $10-20 \mathrm{~cm} / \mathrm{s}$ mencapai $25 \%$. Kecepatan tertinggi $20-30 \mathrm{~cm} / \mathrm{s}$ memiliki frekuensi $6 \%$. Selain itu, arah arus laut mayoritas ke arah tenggara (120-150\%), menunjukkan bahwa arus lebih cenderung sejajar dengan garis pantai yang disebut arus sejajar pantai yang dapat mempercepat garis pantai Desa Serangai, Bengkulu. Namun, penelitian lebih lanjut diperlukan untuk melihat variabilitas arus yang terkait dengan musim (monsun).
\end{abstract}

Kata Kunci : Abrasi; Serangai; Aanderaa Seaguard RCM; Arus Sejajar Pantai

\section{PENDAHULUAN}

Perubahan garis pantai di Provinsi Bengkulu khususnya di daerah Bengkulu Utara sudah sangat mengkhawatirkan. Berdasarkan hasil data satelit, perubahan garis pantai di daerah Bengkulu Utara khususnya di daerah Desa Serangai, Kecamatan Batik Nau mencapai 20 m/tahun (Hanafi, 2019). Perubahan garis pantai ini umumnya berasal dari proses abrasi dan erosi pantai. Abrasi terjadi di pantai Bengkulu Utara terutama 
Desa Serangai, Kecamatam Batik Nau telah merusak infrastruktur seperti kawasan permukiman, sarana dan prasarana publik. Masalah-masalah perubahan garis pantai berpotensi serius karena fenomena abrasi pantai adalah rusaknya fasilitas jalan raya yang menghubungkan Provinsi Sumatera Barat dan Provinsi Lampung yang mempunyai peran yang sangat vital bagi masyarakat Provinsi Bengkulu dan sekitarnya. Menurut Nofirman (2017) Desa Serangai, Bengkulu Utara telah mengalami kerusakan yang sangat parah akibat abrasi yang terjadi secara terus-menerus.

Proses abrasi yang terjadi di daerah perairan pantai Desa Serangai, Bengkulu Utara tidak terlepas dari kondisi geologi/tektonik, maupun kondisi oseanografi fisika/hidrodinamika pada daerah tersebut. Daerah perairan Desa Serangai merupakan pantai yang berhadapan langsung dengan lautan yang terbuka (Samudra Hindia). Kondisi tersebut memungkinkan gelombang laut dan arus laut berpotensi menyebabkan abrasi pantai. Abrasi merupakan proses pengikisan pantai oleh gelombang laut dan arus laut yang dapat merusak profil fisik perairan pantai dipicu oleh terganggunya keseimbangan alam daerah pantai tersebut.

Faktor-faktor yang berperan dalam proses perubahan garis pantai, yakni besarnya energi gelombang laut yang menghempas pantai, sudut yang dibentuk antara muka gelombang laut saat pecah dengan garis pantai, lereng dasar perairan, stuktur bawah permukaan pantai, jenis dan ukuran sedimen yang terdeposit, keterbukaan pantai terhadap hantaman gelombang laut dan bentuk morfologi garis pantai (Purba et al. 2004). Abrasi dapat juga terjadi akibat adanya arus sejajar pantai yang dibangkitkan oleh gelombang laut datang dan gelombang laut pecah yang tidak tegak lurus dengan garis pantai (Umar, (201 1); Twidale et al., (2005); Paul and Rashid (2017). Tinggi gelombang laut yang besar menghasilkan arus menyusur pantai dengan kecepatan yang tinggi, sehingga material pantai semakin banyak yang tergerus atau hilang ke pantai yang lebih dalam yang dibawa oleh arus pantai pada perairan pantai. Gelombang laut yang menyebabkan terjadinya arus sejajar pantai adalah salah satu penyebab utama dari abrasi pantai (Komar (1983); Short, (2006); Jackson et al., (2017); Mörner and Finkl (2019); Saengsupavanich (2019)). Mengingat arus sejajar pantai merupakan salah satu parameter yang berperan dalam proses abrasi pantai, maka tujuan dari penelitian ini adalah untuk mengetahui kecepatan arus laut dan arah dominan dari arus laut dengan menggunakan alat Aandera Seaguard RCM. Dengan mengetahui kondisi oseanografi fisik ini, maka dapat pula diketahui keberadaan dan besarnya arus sejajar pantai (longshore current) di daerah Desa Serangai, Bengkulu Utara.

\section{MATERI DAN METODE}

Pengukuran arus laut dilakukan di perairan Desa Serangai, Bengkulu Utara pada pada tanggal 5-7 November 2018 yang lokasi pengukurannya diperlihatkan pada Gambar 1. Pengukuran arus laut tersebut dilakukan untuk memperoleh data kecepatan dan arah arus laut. Dengan melakukan pemetaan arah arus maka kita dapat menentukan kemana arah arus dominan dan arah arus yang sejajar dengan pantai (longshore current). Pengukuran arus menggunakan alat Aandera Seaguard RCM diletakkan pada koordinat $3^{\circ} 25$. 825' LS dan $101 \circ 53.440^{\prime}$ BT. Alat tersebut diletakkan pada dasar perairan dengan sensor untuk mengukur kecepatan dan arah arus laut. Pengukuran arus dilakukan dengan interval waktu tiap 10 menit. Lokasi pengukuran berada sejauh $\pm 20 \mathrm{~m}$ dari garis pantai, yang diletakkan pada kedalaman $5 \mathrm{~m}$ karena kondisi pantai yang dangkal dan landai (Gambar 2). Pengukuran secara langsung dilakukan untuk mendapatkan infromasi waktu pengukukuran (tanggal, jam, menit), kecepatan arus dan arah arus laut.

Pengukur Arus (current meter) yang digunakan terlebih dahulu dirangkai dengan menggunakan pemberat (Gambar 3), kemudian baru dibawa ke daerah pantai dengan kedalaman $5 \mathrm{~m}$ karena kondisi pantai yang dangkal dan landai di daerah Serangai. Prinsip kerja alat ini menggunakan prinsip Dopler pada transduser, dengan frekuensi tertentu. Gelombang yang 
direfleksikan ataupun proses hamburan oleh partikel-partikel dalam air mengalami perubahan frekuensi dan direkam kembali oleh receiver. Dengan prinsip pergeseran frekuensi ini alah kecepatan arus laut dapat ditentukan. Untuk melihat arahnya maka sensor dipasang dari berbagai macam arah.

Data arus tercatat oleh Aandera Seaguard RCM dengan format XML, diolah dengan menggunakan Software Microsoft
Excel untuk mendapatkan kecepatan dan arah arus arus sejajar pantai. Proses pertama dalam pengolahan adalah ekspor data XML ke file teks ASCII, kemudian seleksi data yang mana saja yang dipergunakan, noise-noise yang juga terekam selama proses akuisisi data dihilangkan. Selanjutnya ditabulasikan data di Microsoft Excel dan ambil komponenkomponen penting seperti bujur, lintang, kecepatan arah Eastward dan Northward. Selanjutnya resultan kecepatan diperoleh

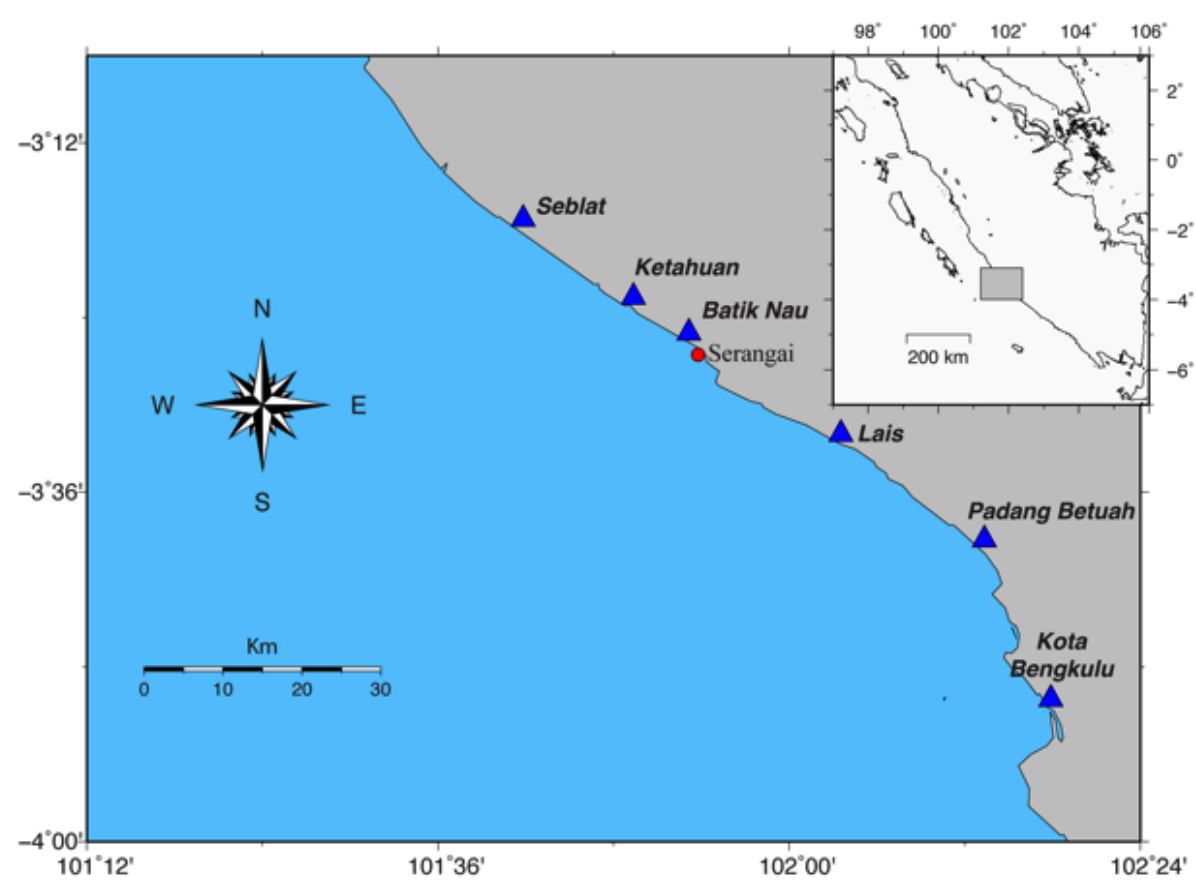

Gambar 1. Lokasi penelitian arus sejajar pantai di Desa Serangai, Bengkulu Utara. Titik merah merupakan titik pemasangan alat Aandera Seaguard RCM. Segi tiga biru merupakan lokasi pemukiman yang utama di daerah Bengkulu dan Bengkulu bagian Utara

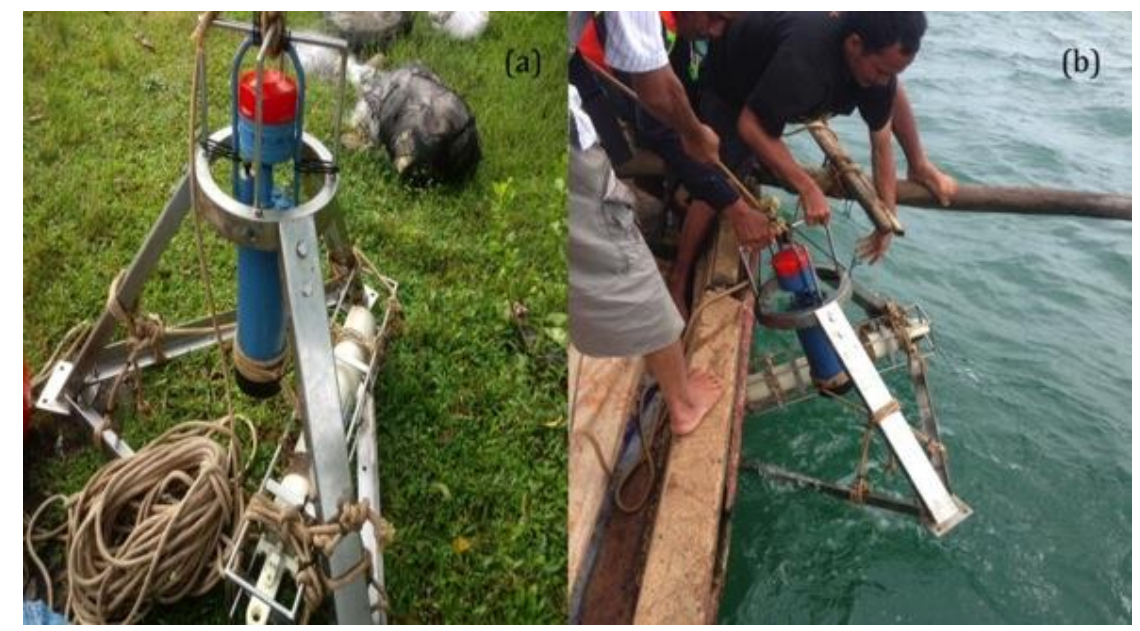

Gambar 2. Gambar alat Aandera Seaguard RCM yang telah diset up dan siap untuk diletakkan di dasar laut (a). Pemasangan alat pada kedalaman laut $5 \mathrm{~m}$ di Desa Serangai (b) 
dengan menggunakan aturan Phytagoras. Setelah proses pengolahan data selesai, maka selanjutnya akan dilakukan analisis untuk mengetahui kecepatan dan arah dominan arus sejajar pantai. Analisis dilakukan dengan menggunakan Software currentrose Pro.

\section{HASIL DAN PEMBAHASAN}

Hasil pengukuran kecepatan arus laut di perairan pantai Desa Serangai, Bengkulu Utara diperlihatkan seperti pada Gambar 3. Dapat dilihat bahwa kecepatan arus laut tertinggi pada tanggal 5 November 2018 sebesar $26,50 \mathrm{~cm} /$ detik pada pukul 10:20 WIB. Dapat dilihat juga bahwa kecepatan arus laut terendah yakni $0,98 \mathrm{~cm} /$ detik pada pukul 13:30 WIB. Kemudian terlihat bahwa kecepatan arus laut tertinggi pada tanggal 6 November 2018 yakni 19,63 cm/detik pada pukul 23:20 WIB dan kecepatan arus laut terendah yakni $0,92 \mathrm{~cm} /$ detik terjadi pada pukul 11:00 WIB.

Pada Gambar 3 kecepatan arus laut pada tanggal 7 November 2018 memiliki nilai tertinggi yakni $27,73 \mathrm{~cm} /$ detik yang terjadi pada pukul 9:30 WIB, sedangkan kecepatan arus laut terndah pada tanggal 7 November 2018 adalah $0,64 \mathrm{~cm} /$ detik pada pukul 13:30 WIB. Pada tanggal 6 November 2018 dimulai terjadi peningkatan kecepatan arus laut, hal ini disebabkan karena pada waktu tersebut terjadi hujan yang disertai angin kencang pada saat pengambilan data di lapangan.
Peningkatan kecepatan angin juga terlihat pada stasiun pengamatan di daerah Bengkulu (Gambar 4). Hal lain juga terlihat bahwa pada waktu tersebut terjadi kenaikan pasang surut sekitar $30 \mathrm{~cm}$ dari hari sebelumnya (Gambar 4). Tinggi kecepatan arus laut dipengaruhi oleh pasang surut dan tingginya kecepatan angin diatas permukaan laut pada saat itu. Hal ini sesuai dengan literatur dimana arus laut merupakan pergerakan suatu massa air yang disebabkan oleh adanya tiupan angin atau perbedaan densitas air laut (Nontji (1993); Hunta and Sajjadib, (2018); Takagaki et al., (2018); Young and Ribal (2019)). Berdasarkan pengamatan kecepatan arus laut di daerah Desa Serangai, Bengkulu Utara telah didapatkan hasil bahwa kecepatan arus laut tertinggi yakni $27,73 \mathrm{~cm} /$ detik pada pukul 9:30 WIB pada tanggal 7 November 2018 dan kecepatan arah arus laut terendah yakni 0,64 $\mathrm{cm} /$ detik pada pukul 13:30 WIB juga pada tanggal 7 November 2018.

Besar kecilnya arus sejajar pantai dipengaruhi oleh tinggi gelombang pecah dan sudut gelombang pecah terhadap garis pantai (Ahdannabiel et al., 2017). Sementara itu tinggi gelombang pecah sngat dipengaruhi oleh kecepatan angin sebagai pembangkit utama penjalaran gelombang. Semakin tinggi gelombang pecah dan semakin besar sudut antara gelombang pecah dan garis pantai, maka kecepatan arus sejajar pantai akan semakin besar (Komar, 1998). Berdasarkan pengamatan di

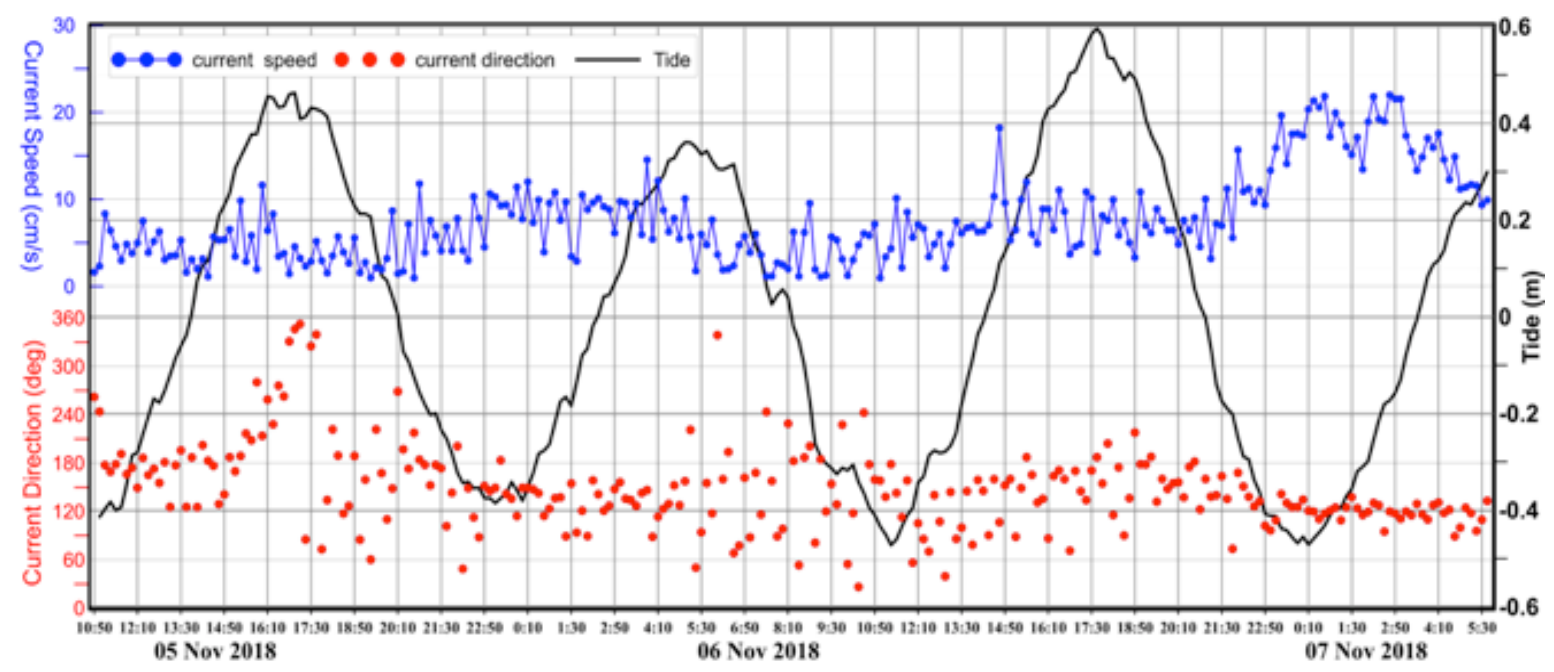

Gambar 3. Grafik kecepatan dan arah arus laut serta pasang surut pada daerah Serangai. 


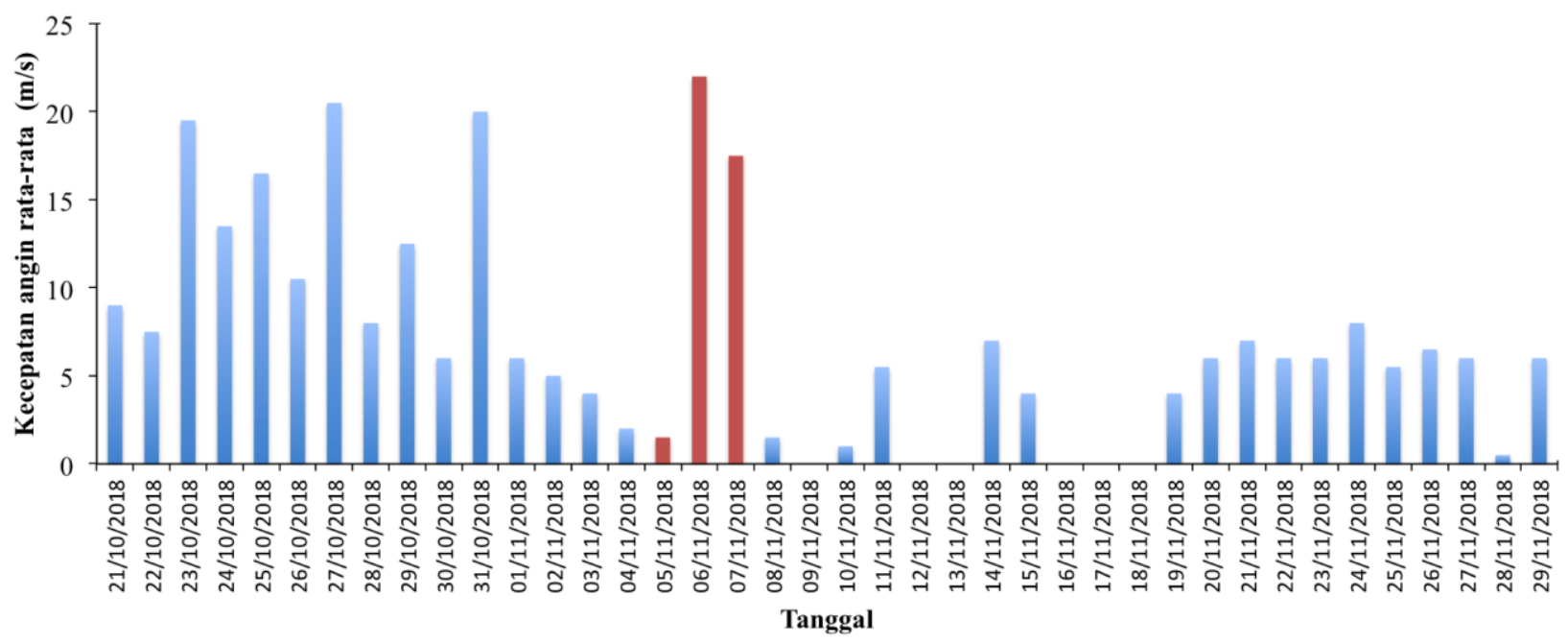

Gambar 4. Grafik kecepatan angin rata-rata di daerah Bengkulu. Bar merah merupakan data angin pada saat pengambilan data arus laut di daerah Serangai.

lapangan sudut antara gelombang pecah dan garis pantai di daerah serangai sekitar 35. Namun demikian besarnya tinggi gelombang pecah masih belum diketahui secara kuantitatif, sehingga masih memerlukan penelitian tentang tinggi gelombang laut beserta periode kedatangannya di daerah Serangai.

Tanggal 5 November 2018, arah arus laut berada pada kisaran 100 $-200^{\circ}$, sedangkan pada tanggal 6 November 2018 arah arus laut berada pada kisaran $120^{\circ}-150^{\circ}$ (Gambar 4). Hal yang sama juga teramati pada arah arus laut pada tanggal 7 November dimana arah arus laut juga berada pada kisaran 120-150 pada saat pukul 00:00 WIB sampai dengan 06:00 WIB. Secara umum berdasarkan hasil pengamatan terlihat bahwa secara arah arus laut berada pada kisaran $120^{\circ}-150^{\circ}$.

Pemetaan arah arus laut yang dominan dipergunakan grafik current rose untuk menggambarkan distribusi arah dan kecepatan arus laut seperti pada Gambar 5. Dapat kita lihat bahwa arah arus laut pada Gambar 5 dominan kearah tenggara (1200$\left.150^{\circ}\right)$ dengan resultan vektor arus berada pada arah $144^{\circ}$ dari arah utara. Hal ini menunjukkan arus laut yang dominan yang diperoleh cenderung sejajar dengan bibir pantai. Arus laut ini yang disebut dengan arus sejajar pantai. Dengan demikian keberadaan arus sejajar pantai di daerah perairan Desa
Serangai, Bengkulu Utara dapat ditemukan secara jelas.

Kecepatan arus laut dominan di daerah perairan Desa Serangai, Bengkulu Utara berkisar pada 0-10 cm/detik yakni mencapai $69 \%$. Sedangkan frekuensi kecepatan arus laut pada rentang 10-20 $\mathrm{cm} /$ detik sebesar 25\% (Gambar 6). Sementara itu kecepatan arus laut pada selang 20-30 cm/detik memiliki distribusi frekuensi sekitar $6 \%$. Perilaku arus laut yang sama dengan penelitian ini juga telah diamati oleh Sugianto dan Agus, (2007) di perairan pantai barat daerah perairan Painan, Sumatera Barat pada bulan November 2004 saat arus musim barat (monsun) pada kedalaman $2 \mathrm{~m}$ dari permukaan. Kecepatan arus laut juga menunjukkan hal yang sama yang mana arus bergerak dengan kecepatan rata-rata 11 $\mathrm{cm} /$ detik, dengan arah dominan adalah ke tenggara hingga selatan dan kecepatan arus laut maksimum yakni $22 \mathrm{~cm} /$ detik.

Arah arus sejajar pantai dipengaruhi oleh angin yang bertiup dan perbedaan densitas air laut (Nontji, 1993). Penelitian dilakukan pada saat monsun barat yang diduga dapat menyebabkan arah arus sejajar dengan garis pantai. Pada Gambar 8 diperlihatkan arah dan besarnya arus sejajar dengan pantai yang diperoleh. Arus sejajar pantai yang diperoleh menuju ke tenggara pada musim arus Monsun barat menuju Kota 
Bengkulu di selatan. Fenomena seperti ini mirip dengan fenomena yang teramati daerah perairan Painan, Sumatera Barat dimana kondisi arus dominan adalah ke tenggara pantai barat daerah Sumatera Barat. Besarnya kecepatan arus sejajar pantai yang terjadi di perairan Desa Serangai, Bengkulu Utara dikarenakan gaya dorong angin yang bertiup diatas laut, hal ini disebabkan karena penelitian ini relatif mengukur arus pada arus (surface current), yaitu pada kedalaman $5 \mathrm{~m}$. Arus yang terukur merupakan arus laut permukaan $<200 \mathrm{~m}$ yang sangat dominan dipengaruhi oleh gaya dorong angin dan pada umumnya bergerak mengikuti arah rambat angin (Purnama, 2009).

Kecepatan arus sejajar pantai yang didapatkan relatif lebih kecil yakni <10 $\mathrm{cm} /$ detik yakni sekitar $69 \%$. Hal ini dapat dimengerti bahwa kecepatan arus sejajar pantai di perairan dalam lebih besar dibandingkan perairan dangkal. Besarnya

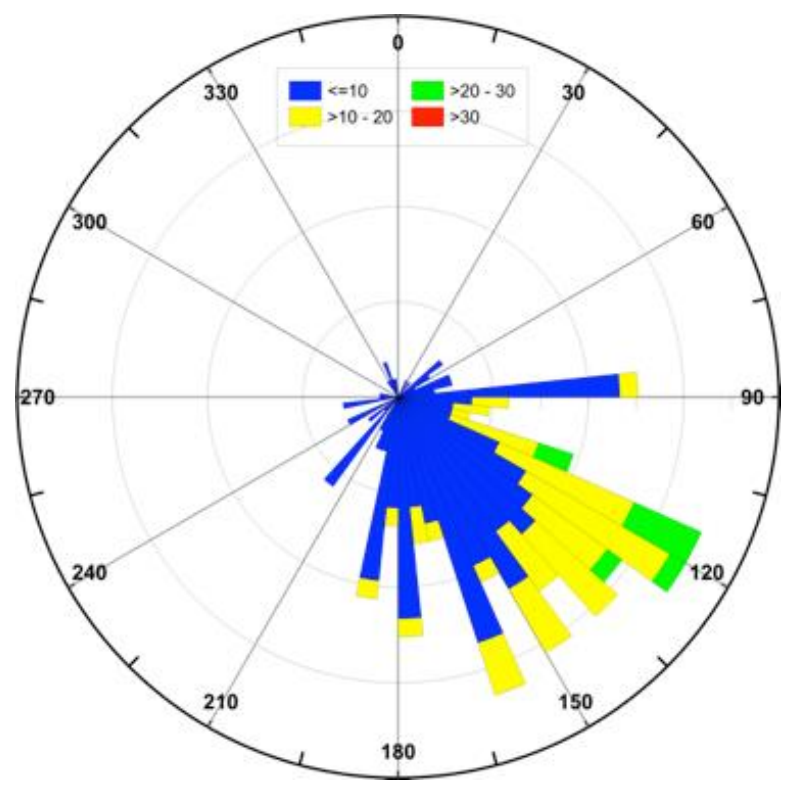

Gambar 5. Diagram current rose yang diperoleh pada penelitian ini. Warna bar merupakan klasifikasi kecepatan arus. Arus laut dominan pada arah $120^{\circ}-150^{\circ}$.

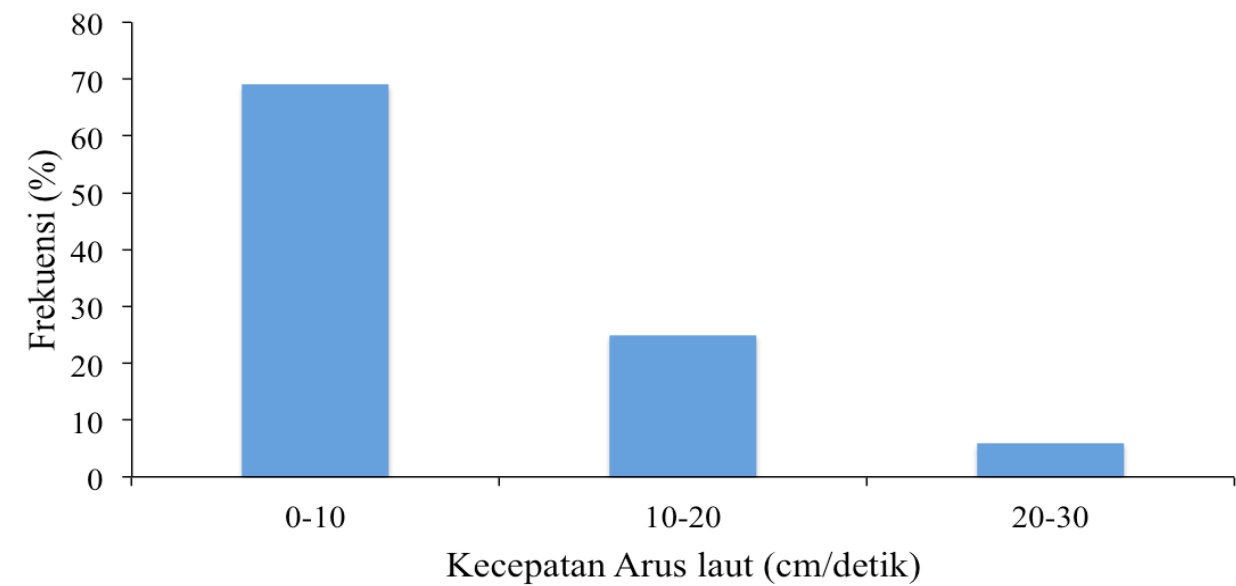

Gambar 6. Distribusi frekuensi kecepatan arus sejajar pantai. Mayoritas kecepatan arus laut berada pada selang $0-10 \mathrm{~cm} /$ detik (lebih kurang 70\%) 


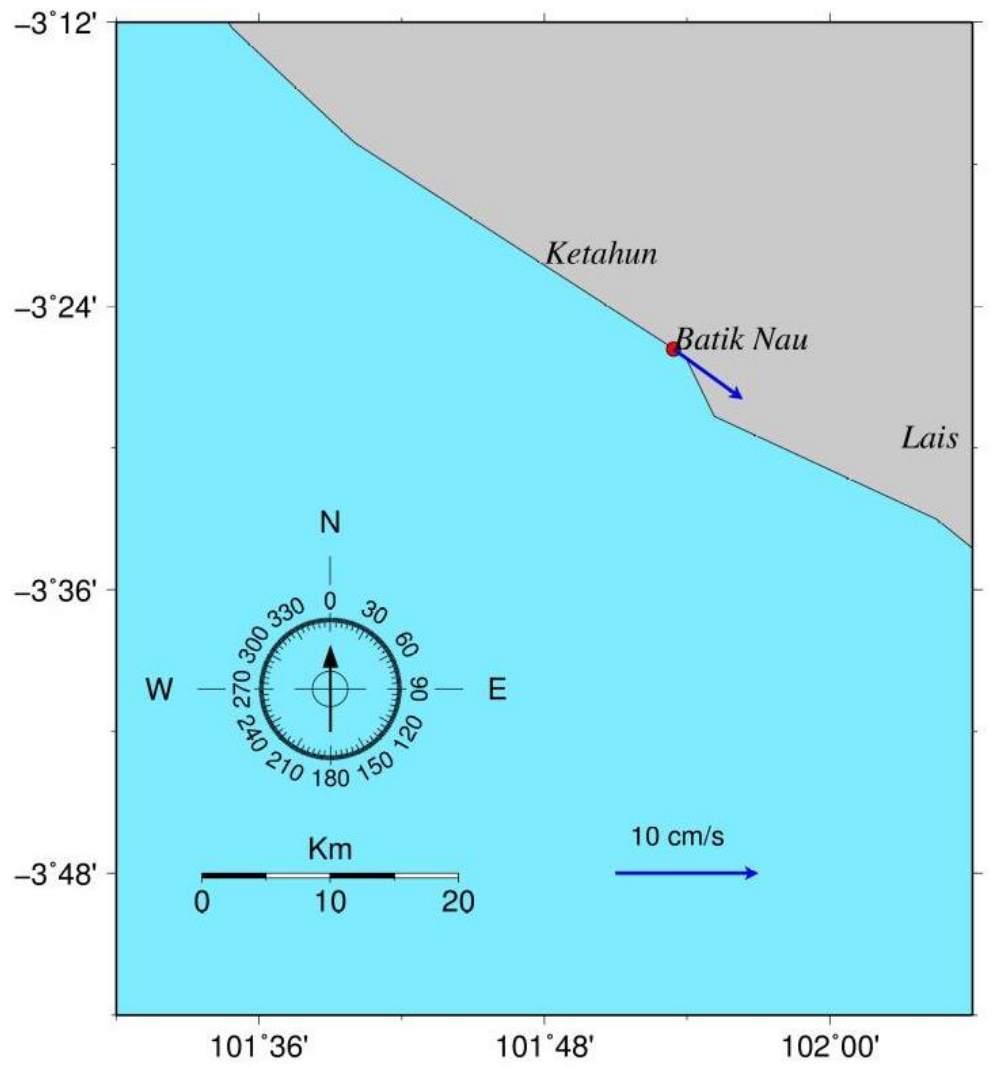

Gambar 8. Arah dan Kecepatan arus sejajar pantai di daerah Serangai

kecepatan arus laut yang terjadi dikarenakan gaya dorong angin yang bertiup diatas laut serta perbedaan kemiringan yang signifikan saat menuju kawasan pantai. Hal inilah yang menyebabkan terjadinya arus sejajar pantai terbentuk setelah gelombang datang dengan kemiringan yang maksimum, gelombang tersebut akan pecah membentuk sudut terhadap garis pantai. Saat gelombang menuju kawasan pantai, arah arus akan mengikuti arah gelombang datang. Arus sejajar pantai yang terjadi mengakibatkan bibir pantai terus menerus tergerus, mengakibatkan material di bibir pantai runtuh dan terbawa oleh arus sehingga menyebabkan terjadinya abrasi Triadmojo (1999).

Peristiwa abrasi sebagian besar disebabkan oleh terganggunya keseimbangan antara suplai sedimen yang masuk dan keluar perairan. Proses pengangkutan sedimen ini dipengaruhi oleh keberadaan arus sejajar pantai dan gelombang pecah (Triatmodjo, 1999). Bila arus sejajar pantai dengan nilai kecepatan $>10 \mathrm{~cm} /$ detik dapat mengangkut yang berdiameter $0,6 \mathrm{~mm}$ sehingga berpotensi menyebabkan abrasi di daerah tersebut (Dronkers, 2005). Kecepatan arus sejajar pantai yang $>10 \mathrm{~cm} /$ detik pada daerah Serangai mencapai frekuensi lebih dari $30 \%$. Dengan pengakutan sediment ini mengakibatkan terjadi abrasi pantai karena daerah tersebut terjadi kekurangan suplai sedimen.

Disisi lain, frekuensi hantaman gelombang laut yang tinggi pada kaki tebing mempercepat abrasi dan menggerus kaki tebing yang dapat menyebabkan lapisanlapisan material runtuh atau bergerak (Sunamur, 1977) terbawa oleh arus laut. Proses penggerusan pantai akibat hempasan arus sejajar pantai dalam jangka waktu yang lama akan menyebabkan proses abrasi menjadi semakin cepat di daeah perairan Desa Serangai, Bengkulu Utara. Oleh karena itu arus sejajar pantai memainkan peranan penting dalam perubahan garis pantai, 
sebagaimana perubahan ringan dari suplai sediment, arah angin atau hal lain yang mempengaruhi arus sejajar pantai dapat merubah secara dramatis, yang berakibat pada abrasi pantai. Mengingat pentingnya mempelajari karakteristik arus sejajar pantai pada daerah ini maka diperlukan penelitian lanjutan untuk melihat pengaruh arus sejajar pantai dan arah dominan arus laut terhadap perubahan musiman seperti musim angin peralihan dan musim angin timur. Informasi tentang karakteristik arus sejajar pantai ini sangat penting untuk memahi pergerakan sediment di daerah perairan Bengkulu Utara.

\section{KESIMPULAN}

Kecepatan arus laut dibagi menjadi tiga kategori yakni kecepatan arus laut pada kisaran 0-10 cm/detik, $10-20 \mathrm{~cm} /$ detik, dan 20-30 cm/detik. Frekuensi distribusi kecepatan arus pada 0-10 cm/detik adalah 69\%, frekuensi distribusi $10-20 \mathrm{~cm} /$ detik adalah $25 \%$ dan frekuensi distribusi $20-30 \mathrm{~cm} /$ detik adalah $6 \%$. Kecepatan arus yang $>10 \mathrm{~cm} /$ detik dapat mengakut sedimen dan menyebabkan abrasi pada daerah Serangai dengan frekuensi lebih dari $30 \%$. Arah arus yang diperoleh dominan ke arah tenggara (120-150 ) memperlihatkan arus laut cenderung sejajar dengan garis pantai. Hal ini dapat disimpulkan bahwa keberadaan arus sejajar pantai di daerah perairan Desa Serangai, Bengkulu Utara dapat teramati dengan jelas dan lebih dominan selama masa pengamatan dengan resultan vektor arus sejajar pantai menunjukkan pada 1440. Fenomena ini menandai bahwa di perairan Desa Serangai, Bengkulu Utara memiliki kecepatan dan arah arus cenderung sejajar dengan bibir pantai yang dapat menjadi salah satu agent dalam penggerusan bibir pantai yang secara terus menerus tergerus dan mengakibatkan material di bibir pantai runtuh dan terbawa oleh arus sehingga menyebabkan terjadinya abrasi pada daerah ini. Penelitian lanjutan tentang arus laut termasuk ketinggian gelombang pada daerah ini masih sangat diperlukan memahami karakteristik arus sejajar pantai dan arah dominan arus laut terhadap perubahan musiman seperti musim angin peralihan dan musim angin timur.

\section{UCAPAN TERIMA KASIH}

Penulis mengucapkan banyak terima kasih kepada P2O LIPI yang telah mengijinkan penggunaan alat Aandera Seaguard RCM. Penulis juga mengucapkan terimakasih kepada kru kapal untuk pengambilan data dan kepada mahasiswa Jurusan Fisika yang telah banyak membantu dalam pengambilan data di lapangan. Penelitian ini didanai oleh program Demand Driven Research Grant (DDRG) tahun 2018 melalui kegiatan Coral Reef Rehabilitation and Management Program-Coral Triangle Initiative (COREMAP-CTI), LIPI.

\section{DAFTAR PUSTAKA}

Ahdannabiel, H., Widada, S., \& Hariadi. 2017. Distribusi Sedimen Dasar Akibat Arus Sejajar Pantai di Sekitar Groin di Perairan Pantai Widuri Pemalang, J. Oseanograf., 6(4):650-658.

Dronkers, J. 2005. Dynamics of Coastal Systems, World Scientific, Singapore.

Hanafi, R. 2019. Perubahan garis pantai di daerah Bengkulu Utara dengan Metode UAV. Skripsi. Program Studi Fisika. Fakultas MIPA: Universitas Bengkulu.

Hunta, J.C.R. \& Sajjadib, S.G. 2018. Mechanisms And Modelling of Wind Driven Wave, Procedia IUTAM, 26:3-13.

Jackson N.L., Nordstrom K.F. \& Farrell E.J. 2017. Longshore sediment transport and foreshore change in the swash zone of an estuarine beach, Mar. Geolog., 386: 88-97

Komar, P.D. 1983. Handbook of Coastal Processes and Erosion. CRC Press, Inc. Boca Raton. Florida. USA.

Komar, P.D. 1998. Beach Processes and Sedimentation. Second Edition, Printice Hall, New Jersey, USA.

Mörner, NA., \& Finkl, C.W. 2019. Coastal Erosion. In: Finkl C.W., Makowski C. (eds) Encyclopedia of Coastal Science. Encyclopedia of Earth Sciences Series. Springer, Cham.

Nofirman. 2017. Perubahan Morfologi Pantai Dengan Integrasi Citra di Wilayah Kabupaten Bengkulu Utara. J. Georafflesia, 2(2):42-60

Nontji, A. 1993. Laut Nusantara. Penerbit Djambatan, Jakarta. 
Paul, B.K. \& Rashid, H. 2017. Coastal Landform Changes: Coastal Erosion, Land Accretion and Subsidence, Climatic Hazards in Coastal Bangladesh, NonStructural and Structural Solutions, Elsevier Inc. pp 121-152.

Purba, M. \& Jaya, I. 2004. Analisis Perubahan Garis Pantai dan Penutupan Lahan Antara Way Panet dan Way Sekampung, Kabupaten Lampung Timur. J. Ilmu Perair. Perikan. Indo., 11 (2): 109-121.

Purnama, S. 1992. Petunjuk Praktikum Oseanografi. Laboratorium Geomorfologi Dasar, Fakultas Geografi Universitas Gajah Mada, Yogyakarta.

Saengsupavanich, C. 2019. Willingness to restore jetty-created erosion at a famous tourism beach. Ocean Coast. Manag., 178:104817.

Short, A.D. 2006. Australian beach systems Nature and distribution. J. Coast. Res., 22:11-27.

Sugianto, D.N. \& Agus, A.D.S. 2007. Studi Pola Sirkulasi Arus Laut di Perairan Pantai
Provinsi Sumatera Barat. IImu Kelautan, 12(2):79-92.

Sunamura, T. 1977. A relationship between wave-induced cliff abrasion and abrasive force of wave. J. Geolog., 85:613-618.

Takagaki N., Komori S., Iwano K., Suzuki N., \& Kumamaru, H. 2018. Generation method of wind waves under long-fetch conditions over a broad range of wind speeds, Procedia IUTAM, 26:184-193.

Twidale. C.R., Bourne. J.A., \& Romani. J.R.V. 2005. Beach etching and shore platforms, Geomorpholog., 67(1-2):47-61.

Triatmodjo, B. 1999. Teknik Pantai, Beta Offset, Yogyakarta.

Umar. 2011. Kajian Pengaruh Gelombang Terhadap Kerusakan Pantai Matang Danau Kabupaten Sambas. Universitas Tanjung Pura: Pontianak.

Young. I.R. \& Ribal, A. 2019. Multiplatform evaluation of global trends in wind speed and wave height, Sci., 364(6440): 548-552. 